\title{
The 21 February 2005, catastrophic waste avalanche at Leuwigajah dumpsite, Bandung, Indonesia
}

\author{
Franck Lavigne ${ }^{1 *}$, Patrick Wassmer ${ }^{2,3}$, Christopher Gomez ${ }^{3}$, Thimoty A Davies ${ }^{4}$, Danang Sri Hadmoko ${ }^{5}$, \\ T Yan W M Iskandarsyah², JC Gaillard ${ }^{6}$, Monique Fort ${ }^{7}$, Pauline Texier ${ }^{8}$, Mathias Boun Heng ${ }^{1}$ \\ and Indyo Pratomo ${ }^{9}$
}

\begin{abstract}
Background: On 21 February 2005 the Leuwigajah dumpsite, Bandung (Java, Indonesia) was affected by a large slide after heavy rainfalls. Second deadliest waste slide in history, it buried 71 houses and killed 143 people. Amongst the contemporary disastrous events of this type, only a few have been documented. We explored failure preconditions, triggering mechanisms and local context that conducted to this disaster. We carried on four field investigations on the site. A series of aerial photographs were acquired and completed by topographical measures on the ground. The morphology of the slide and its trajectory were reconstructed. To constrain the movement condition, we studied the internal structure of the source area and realized surveys among stakeholders of the dumpsite and citizen.

Results: $2.7 \times 10^{6} \mathrm{~m}^{3}$ of waste materials spread $1000 \mathrm{~m}$ from the source in a rice field with an average thickness of $10 \mathrm{~m}$. The material displays a preferential fabric parallel to the previous topography. Numerous internal slip surfaces, underlined by plastic bags explain the low friction coefficient. The presence of methane within the waste dump was responsible for explosions prior to sliding and for the fire that affects whole sliding mass.

Conclusions: Resulting of a combination of heavy rainfall and consecutive explosions due to biogas sudden release, this disaster was predictable in reason of

i) a front slope of the dump of about $100 \%$ before the failure;

ii) a poor dumpsite management;

iii) the extreme vulnerability of the marginalized scavengers living at risk at the foot of the instable dump.
\end{abstract}

Keywords: Dump-slide; Waste instabilitytriggering factors; Waste management; Precondition factors; Bandung; Indonesia

\section{Background}

A landfill site or dumpsite is a site for the disposal of waste materials by burial. Although progressively replaced by alternative methods like incineration, this technique remains very common around the world, especially in developing countries. Stability of landfills is one of the major geotechnical issues in landfill management. Despite

\footnotetext{
* Correspondence: franck.lavigne@univ-paris1.fr

'UMR 8591 Laboratoire de Géographie Physique, Paris 1 - Panthéon

Sorbonne University, Meudon, France

Full list of author information is available at the end of the article
}

a wide range of industrial hazardous accidents that have occurred worldwide in and around the vicinity of dumpsites, only a handful of contemporary disastrous solid "wasteslides" or "waste avalanches" have been documented. Such events have occurred in western postindustrial countries (e.g. in Kettleman, California, in 1988, Cincinnati, Ohio and Coruña, Spain in 1996, or Athens in 2003), but it is only in developing countries that they have led to major disasters: the deadliest event of this type killed 278 people in Payatas in the vicinity of Manila, Philippines in 2000 (Bernardo 2004; Merry et al. 
2005; Palaypayon and Ohta, 2007; Gaillard and Cadag 2009). Among these disasters, the second deadliest event in history took place on 21 February 2005 at $02.00 \mathrm{am}$ at the Leuwigajah dumpsite, in the vicinity of Bandung city, Java, Indonesia (Figure 1). The waste slide buried 71 houses and killed 143 people.

For landslide analysis, precondition factors are generally related to slope, lithology, geological structure, and soil. In a municipal dumpsite, the conditions that govern the landfill stability are more difficult to assess. Shear strength of the municipal solid waste is a function of many factors such as waste type, composition, compaction, daily cover, moisture conditions, age, decomposition, overburden pressure, etc. (Huvaj-Sarihan, and Stark 2008; Stark et al. 2000; Bray et al. 2009). In addition, the triggering factors of waste slides are more complex than for landslide initiation, due to frequent explosions in the dumpsites. The motion processes of the waste avalanches are also complex and poorly known.

Focusing on the 2005 Leuwigajah disaster, the present contribution aims to present: (1) the factors of the failure; (2) the reconstruction of the motion mechanism of the waste slide; (3) the identification of the underlying causes of the disaster.

\section{Waste management operation activities in the Leuwigajah dumpsite}

The total amount of waste generation in Indonesia is estimated at about 39 million t/year (Yachiyo Engineering Co. 2009). To better understand the context of waste management of large cities in Java Island, the Figure 1 illustrates the waste management operation activities in Jakarta (Texier 2009; Pasang et al. 2007). Before reaching the final disposal site (TPA), the garbage is the object of a series of transitional processes (Figure 2). Solid waste management strongly depends on the availability of land to be used as TPA.

For decades, several dumpsites have operated in Bandung Metropolitan area, which has approximately 6 million inhabitants. In 2005, solid waste generation in this region exceeded $14,000 \mathrm{~m}^{3}$ per day (Sundana 2005), of which more than half was generated within Bandung city. Household activities produced the highest volume of waste $\left(7700 \mathrm{~m}^{3}\right.$ per day), followed by industrial waste (3200 $\mathrm{m}^{3}$ per day) and public facilities $\left(1400 \mathrm{~m}^{3}\right.$ per day). Out of the whole volume of waste produced in the metropolitan area, only $46 \%$ was collected (Sundana 2005). Most of the uncollected waste was dumped in the rivers (mainly the Citarum River), burned by the population or buried in the backyard.

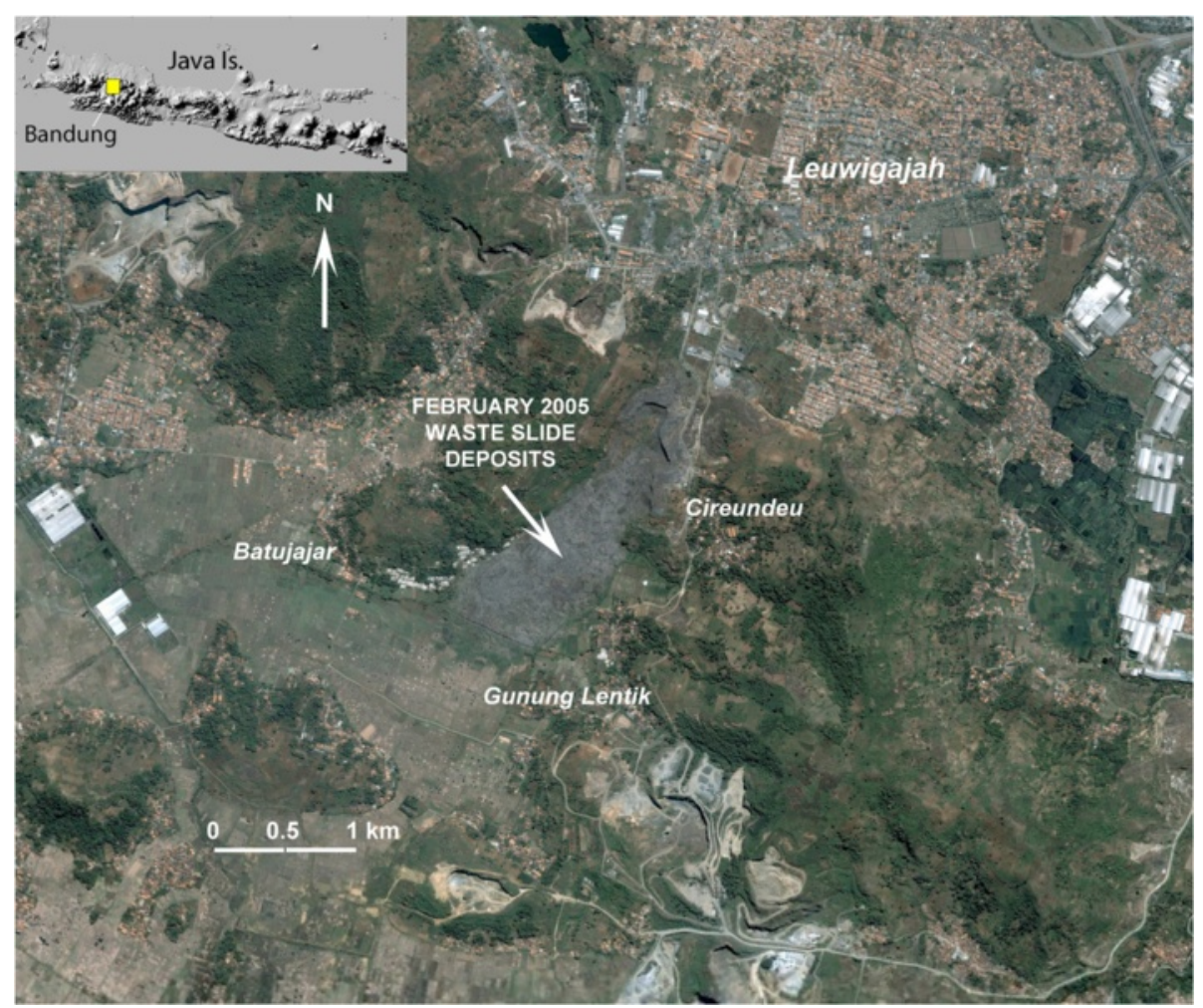

Figure 1 Location of the 21 February 2005 waste avalanche at Leuwigajah, Bandung, in Java Island. High-resolution satellite image as of 3 August 2006 (source: GoogleEarth). 


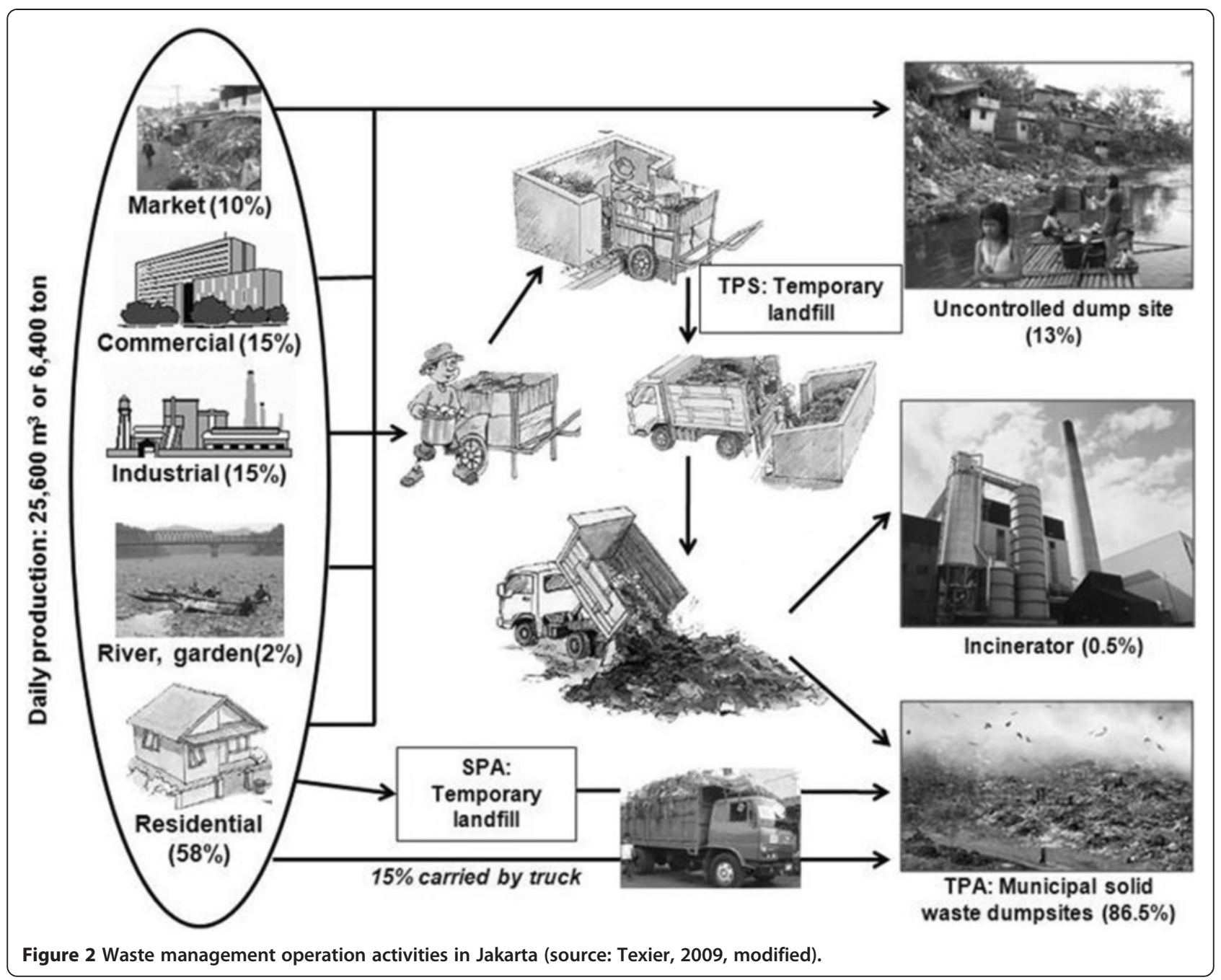

In 1982, the local administration of the city of Bandung chose the small valley-head of Leuwigajah, a neighborhood of Cimahi, to locate the largest waste disposal for the urban centre. The geological setting consists of volcanic rock (mainly andesite) covered by a thin layer $(1 \mathrm{~m})$ of silt or clay material. Before the dumpsite was set up in 1987, small water streams ran through the small valley, mainly during the wet season from October to April. The dumpsite was operated by three different authorities: the City of Bandung, the District of Bandung, and the City of Cimahi. More than $4500 \mathrm{t}$ ( or $750 \mathrm{~m}^{3}$ ) municipal solid waste per day were delivered daily to this dumpsite before the disaster occurred. About $50 \%$ of the inhabitants of the two villages located downslope (Leuwigajah and Batujajar) were working on the dump. With a metal hook in one hand and a plastic bag in the other, they methodically rummaged for reusable waste on the deposit from morning to evening. It is within this context of ill-management that the 21 February 2005 part of the mount created by the garbage slid down.

\section{Methods}

A few months after the disaster, our international team carried out a first field survey, which was followed by three field surveys between 2005 and 2007. The field surveys have combined a variety of geological and geographical techniques. At the deposit scale, a series of aerial photographs acquired by Ultra-Light Motorized (ULM) three days after the disaster by the Department of Engineering Geology of the Institute of Technology of Bandung (ITB) provided data of the length, width, and surface of the waste slide deposit. At a meter to sub-meter scale, we completed the $2 \mathrm{D}$ planar data with vertical measures - like the height of the scarp - that we measured using a handheld laser range finder (LaserAce 300). Using a compass, we defined the orientations of the sliding surfaces of the plastic waste and the orientations of the deposits. The compilation of the orientation data, revealed the direction of the waste during motion. Based on this dataset, we used traditional methods of landslide deposits, in order to understand the complex 
transport mechanisms. Field investigation was carried out in the medial part of the deposit where the material had not been disturbed after the event, i.e. upstream from the location of the buried villages. However, heterogeneous waste composition (Figure 3), obstacles in determining waste strength parameters, and a lack of knowledge about the principles of waste mechanics result in considerable uncertainties in stability calculations. Therefore such calculations were not considered in this study.

Interviews were aimed at obtaining a better understanding of the dumpsite management and the disaster's phenomenology. Key respondents included the chief of the Directorate of Volcanology and Geological Hazards Mitigation, the dumpsite security guard, the staff of the administration in charge of the landfill management, and others. Other interviews were conducted with eyewitnesses of the event, including scavengers and inhabitants of the buried villages. Collected data included information about the number of explosions, the direction of the surges, and the timing of the waste avalanche. In addition to the field investigations, additional secondary data were compiled from different sources on waste cohesion and internal friction angle of the deposit (Koelsch et al. 2005), and gas content within the landfill (P.T. Perusahaan Gas Negara and Perusahaan Daerah Kebersihan Kota Bandung 2000).

\section{Results}

Analysis of waste deposits: a key to reconstruct the waste avalanche dynamics

\section{Morphometry of the waste deposits}

Five months after the February 2005 disaster, the upstream part of the dumpsite displays a $10 \mathrm{~m}$-high scarp cutting the waste accumulation (Figure 4). At the base of the scarp, the waste deposits are very thin or absent because they have been washed away during the 2005

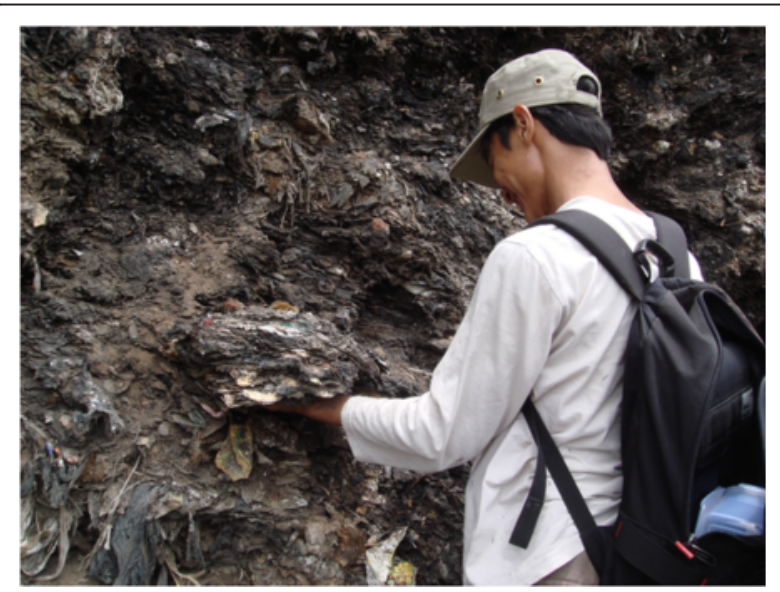

Figure 3 Sampling of the waste deposits (photo: F. Lavigne, February 2007). event. The Figure 4 clearly shows that the gradient of the natural slope was very high, in the order of $45^{\circ}$.

The whole mass of waste spread $1000 \mathrm{~m}$ from the source and covered a 180-340 m wide strip in the rice fields (Figure 5), with an average thickness of about $10 \mathrm{~m}$, although the thickness varied greatly. The overall volume of the displaced waste was initially estimated at $1 \times 10^{6} \mathrm{~m}^{3}$ (Sub-Direktorat Mitigasi Bencana Geologi 2005), before being reviewed from $2.7 \times 10^{6} \mathrm{~m}^{3}$ (Koelsch et al. 2005) to $3.5 \times 10^{6} \mathrm{~m}^{3}$ (Yachiyo Engineering Co. 2009). The morphology of the deposit is similar to an alluvial fan, but with margins characterized by steep slopes with lateral ridges.

\section{Structure and composition of the waste deposits}

The deposit's structure displays different waste layers, which correspond to independent units. Washed by the rain, plastic bags constitute the main part of the material within the upper layers of the dump mass. Most of this material was found burnt due to the gas release, as were the bodies of the victims.

Below the surface, the layers comprise plastic bags remnants mixed with soil and a fine-grained matrix of decomposed organic garbage. Other materials found within the deposits were plastic pieces, stones, pieces of wood, metallic material etc. The main part of the deposit displays a finely foliated structure generally underlain by remainders of plastic bags. All the material shows a preferential fabric rather parallel to the previous topography. Outcrops conform to the displacement direction are showing undulating discontinuities that delimit 5 to $30 \mathrm{~cm}$ thick stratified layers (Figure 6).

\section{Reconstruction of the waste avalanche dynamics}

The independent layers of the waste deposit suggest that during the motion, basal layers stopped while upper layers were still moving, so the stationary base rose incrementally, increasing the deposit volume. The undulating discontinuities seem to correspond to friction surfaces between the layers. The morphology of the deposit, similar to an alluvial fan with steep slopes margins, also suggests that the movement could have been a flow. Therefore it is assumed that the movement can be likened to a debris avalanche, beginning by sliding then evolving to a flow. It seems that the movement was rapid; people had no time to escape although shelter was only $100 \mathrm{~m}$ away. Most of the victims were found in groups inside their houses.

In order to compare motion characteristics of the waste avalanche to the one of the debris avalanches, the effective friction angle of the material can be estimated. As the distance from the source to the rice fields is $1000 \mathrm{~m}$ and the difference of elevation between the scar and the distal part of the deposit is $\sim 100 \mathrm{~m}$, the $\mathrm{H} / \mathrm{L}$ ratio is 0.1 . This low coefficient indicates an efficient 


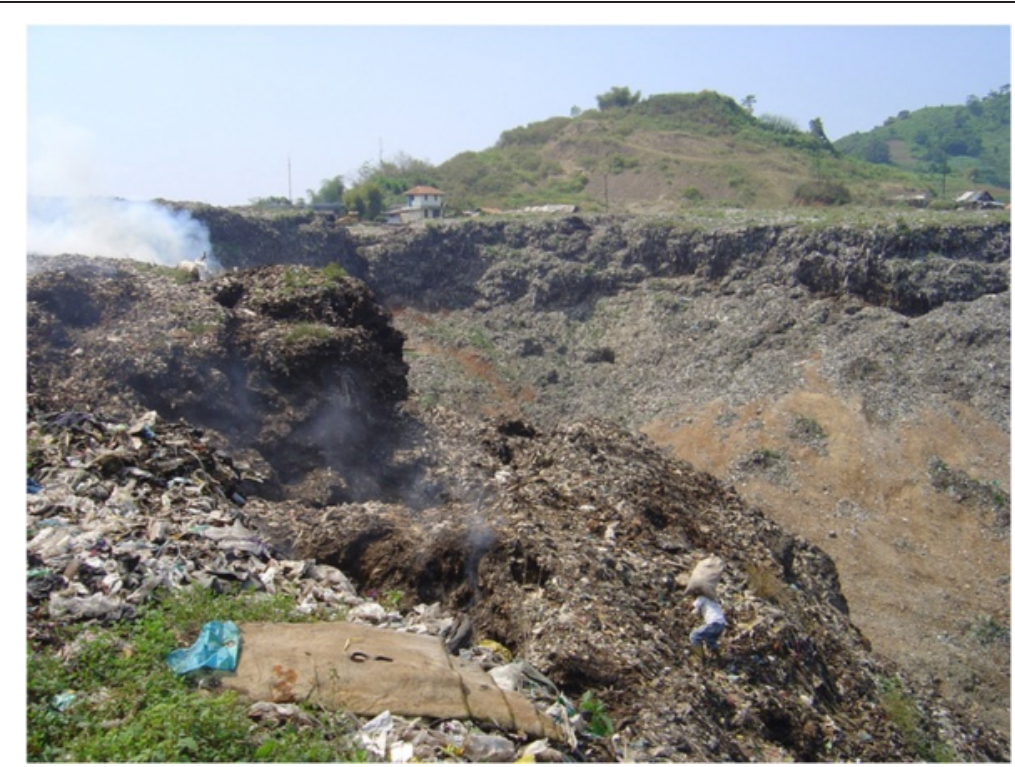

Figure 4 Scarp of the dumpsite after the February 2005 disaster. In the foreground, a scavenger carrying reusable material from the dumpsite. In the background, the steep natural slope in brown color (photo: F. Lavigne, July 2005).

internal friction reduction at the base or within the moving mass. In the case of the Leuwigajah waste avalanche, it is assumed that the high content of plastic bags was responsible for the internal friction reduction as mentioned above.

\section{Origins of the waste slide \\ Precondition factors of the failure}

The procedure for waste disposal was initially regulated (control landfill), however it progressively evolved to an uncontrolled open dump without any regulation (P.T. Perusahaan Gas Negara and Perusahaan Daerah Kebersihan Kota Bandung 2000).

The great heterogeneity of the waste material, mainly comprising a mixture of plastic bags, pieces of clothes, metallic debris, wood, fine-grained material of organic origin etc. make it difficult to sample the undisturbed material (Figure 3). Therefore, we did not calculate the key parameters for slope stability analysis such as cohesion or internal friction angle.

In the months preceding the 2005 disaster, fires have been reported at the Leuwigajah dump site. Eyewitnesses reported that the waste mass was on fire while moving. Fires may have spread quickly because the landfill contained highly flammable combustible material. All the bodies of the victims were burnt, and the studied material was rather deeply charred. Where fires burn quantities of flammable organic materials, such as plastics, temperatures may be very high in the burning zone. This can then ignite methane in the presence of the oxygen (Woodward 1997). Deep-seated fires are found at depth in material deposited weeks, months, or years earlier.
The common cause of deep-seated fires is an increase in the oxygen level within the landfill, which increases aerobic bacterial activity causing a temperature rise. Deepseated fires have the potential to: (i) create large voids, invisible from the surface, which can cause cracking and subsidence of the landfill surface; and (ii) produce flammable and toxic gasses, e.g. carbon monoxide, a toxic gas extremely flammable. It is flammable when mixed with air at concentrations between $12 \%$ and $75 \%$ (Woodward 1997).

An additional factor contributing to the waste slide was the natural instability of the hillslope at the dumpsite. Geologically, the bedrock of the dumpsite is welded volcanic materials (i.e. andesitic volcanic breccia and grain-supported breccia) covered by a thin layer of silt or clay soil. These parent slope materials have a relatively low permeability. Therefore they prevented drainage and acted as a slip surface for the overlying waste materials that were saturated by infiltrating rainwater. After the 21 February 2005 event, small shallow landslides were identified in the weathered pyroclastic material along the scarp. These landslides were probably triggered by the release of the pressure applied by the dump material on the valley walls in the immediate aftermath of the event.

\section{Triggering factors of the failure}

The analysis of the deposit and the interviews have lead to the identification of two direct triggering factors for the waste slide initiation:

(1) Explosion due to sudden biogas release has been identified as the main factor that has triggered the waste 

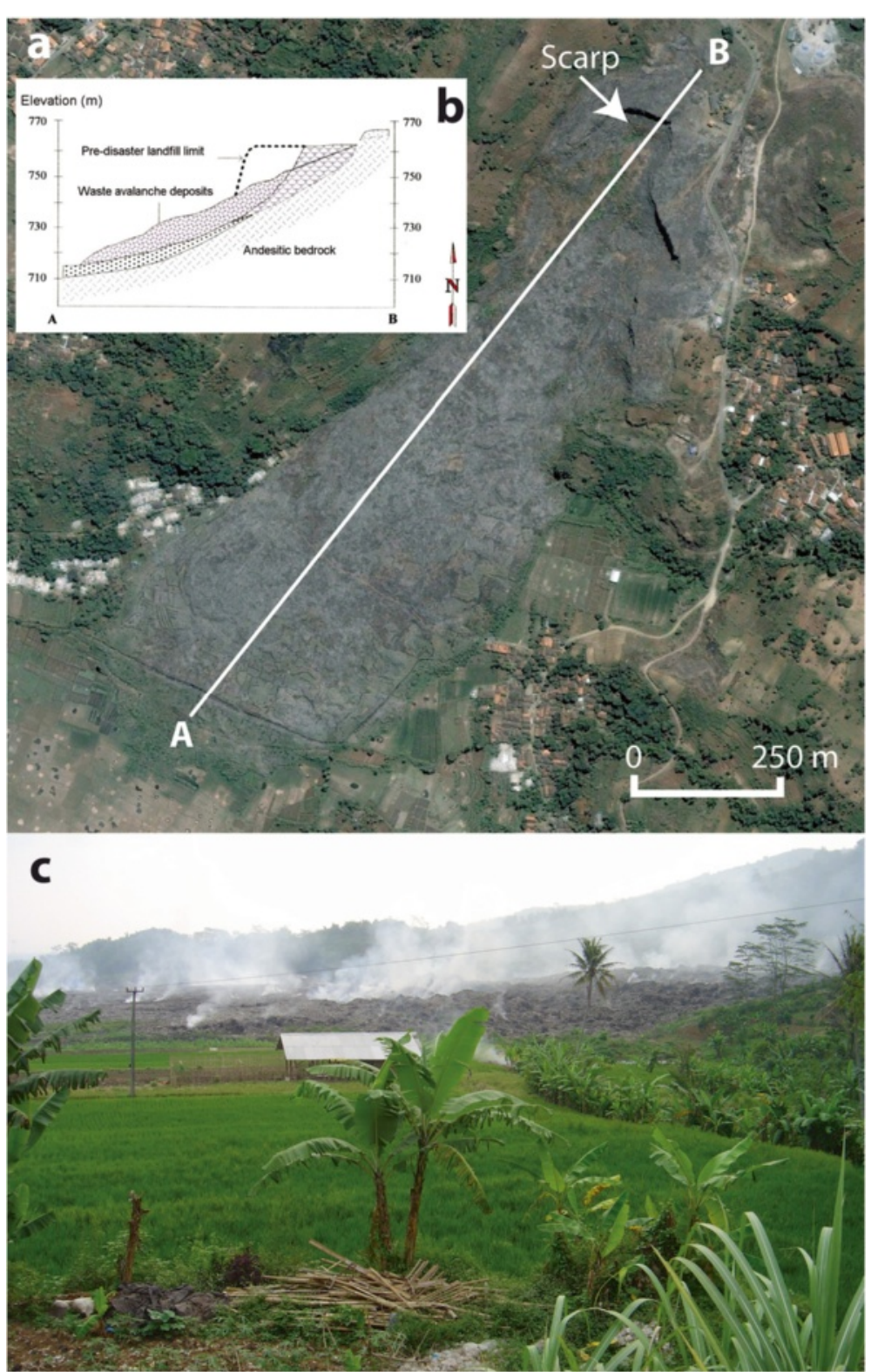

Figure 5 Deposits of the 21 May 2005 waste avalanche at Leuwigajah. (a) Aerial view on 3 August 2006 (source: GoogleEarth).

(b) Longitudinal profile. Dotted area: regolith and soil; (c) Picture of solid waste deposits overlapping rice fields. Notice the smoke emissions attesting permanent deep combustion (photo: F. Lavigne, 22 July 2005).

slide. People living in Leuwigajah and Batujajar heard three almost simultaneous explosion-like sounds a few minutes before the slide. They all insisted that the sound was muffled and seemed to come from deep in the ground. A survey in February 2000 in the Leuwigajah dumpsite indicated a $\mathrm{CH}_{4}$ content of $2.3 \%$ per volume of gas at a $2 \mathrm{~m}$ depth, and almost $5 \%$ at a $4 \mathrm{~m}$ depth (P.T. Perusahaan Gas Negara and Perusahaan Daerah Kebersihan Kota Bandung 2000). It can be assumed that the $\mathrm{CH}_{4}$ concentration would have been higher than these values at higher depths. Yet explosion in a dump site may occur if the proportion of $\mathrm{CH}_{4}$ in the air ranges from $5 \%$ to $15 \%$ (Esmaili 1975). Above 15\%, the biogas ignites but doesn't explode. The explosion hazard was therefore implicit a few years before the 2005 disaster.

The explosions may have resulted from three factors related to the deep-seated fires described above (see 4.2.1).: (i) build-up of landfill gas in enclosed spaces, (ii) ignition of flammable (e.g. plastic bags) or explosive material deposited in the landfill, and (iii) bursting of sealed drums, cans, aerosol containers or gas bottles deposited in the landfill. 


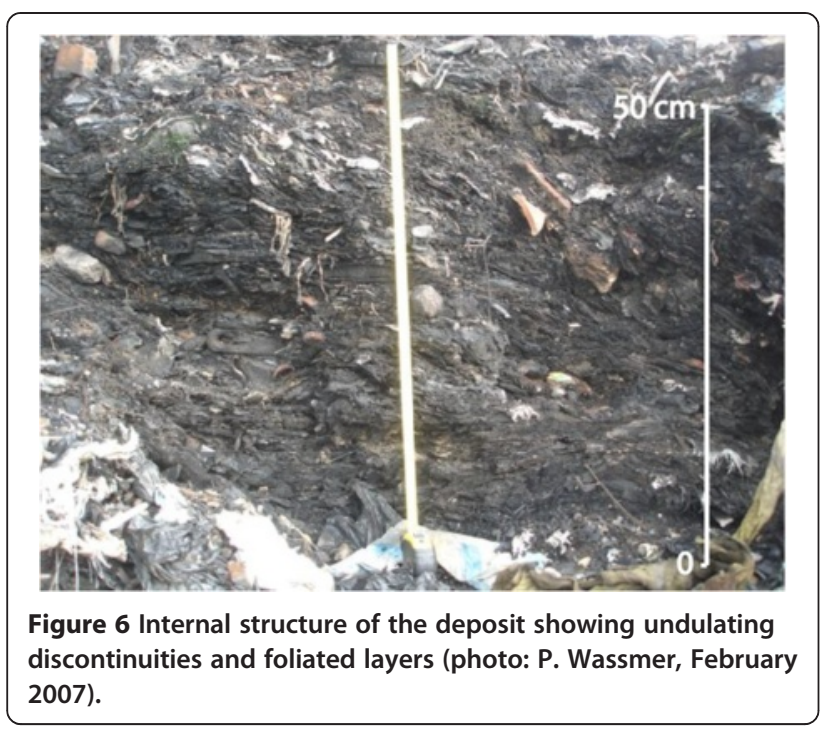

The explosion would have caused a substantial disturbance (quick increase in shear stress or decrease in shear strength) of the saturated waste material. This scenario is also supported by pieces of plastic bags still in place along the post-disaster scarp of the dump (Figure 7) displaying some horizontal orientations (mostly from $\mathrm{N} 196^{\circ}$ to $\mathrm{N} 238^{\circ}$ ), i.e. parallel to the contour line.

(2) The second triggering factor is meteorological. Three days of heavy rainfall (over $80 \mathrm{~mm}$ per day) prior to the failure increased the weight of the waste and the pore-water pressure in the soft subsoil. Water was reported seeping from under the dump three hours before the slide, seeming to indicate that at that time the deposit was saturated. Hence a sudden rise of pressure could be at the origin of both the muffled noise and destabilization of the dump mass. However, it remains unclear whether the explosion led to the slope failure or

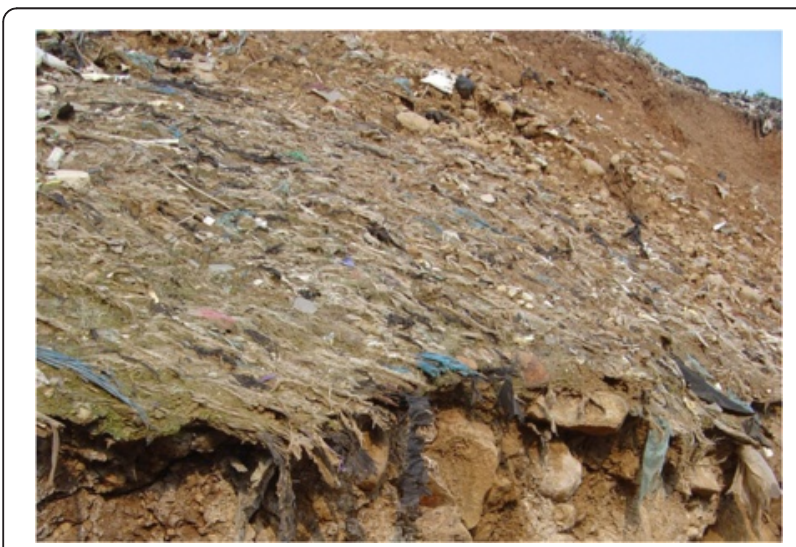

Figure 7 Pieces of plastic bags displaying horizontal orientations along the post-disaster scarp of the dump (Photo: F. Lavigne, July 2005). if the failure, allowing oxygen to reach the combustion zone, triggered the explosion.

\section{Discussion}

An unusual combination of triggering processes

The triggering mechanisms of the waste collapse combined water saturation of the waste deposit, water vaporization, and explosion although these triggers are usually distinct. Thus most of the failures in dump sites relates to heavy rainfall, e.g. the 10 July 2000 disaster at Payatas, the largest dumpsite of Manila city, which occurred following the occurrence of two typhoons. However, waste slides may be also generated without rain, by, either increasing of pore water pressure due to leachate circulation, e.g. during the 8 September 2006 waste slide at the Bantar Gebang dumpsite (Bekasi, Jakarta), or by explosion, e.g. in 1993 at Gembloux, Belgium, or in 1995 at Skellingsted, Denmark (Kjeldsen and Fisher 1995).

\section{Difficulties and attempts to assess dump instability}

Whatever the triggering processes, disasters related to waste avalanche always occur in critical or unstable dumpsites. However, geotechnical data are usually poorly documented due to the difficulty of sampling undisturbed waste deposits (Figure 3), which are typically heterogeneous and very fibrous (Stark et al. 2000). Besides, the properties of the waste fill layer are difficult to measure by laboratory or field tests due to their heterogeneity. In addition, the physical and chemical properties of the deposits rapidly evolve over time due to the change of waste thickness and to the progressive waste decomposition (Blight and Fourie 2005). Lastly, the pore water pressure also varies over time within the waste deposits, as shown at the Doña Juana dumpsite in Bogota by Caicedo et al. (2002). Nevertheless, stability calculations have been carried out. The main parameters influencing the factor of safety were calculated using conventional methods used in soil mechanics: at Payatas and Doña Juana dumpsites (Table 1), cohesion values $(C)$ of about 2 tons $/ \mathrm{m}^{2}$ were obtained, and the internal friction angle $(\varphi)$ ranged from 23 to $28^{\circ}$ (Merry et al. 2005, GeoSyntec Consultants 1998). However, the geotechnical characteristics of waste deposits led other researchers to use more specific methods, more adapted to stability calculation on landfills. For example, the calculation method used by Koelsch (1996) considers the reinforcement effect, which is generated by tensile forces in fibres and foils. The mobilization of tensile forces depends on the normal stress on the fibres. Tensile stress and normal stress are related by a linear function, which is mathematically described by the internal angle of tensile stress $\zeta$. The component of shear strength which is created by tensile forces is called fibrous cohesion (Bray et al. 2009). The fibrous cohesion is calculated from the internal angle of 
Table 1 Documented wasteslide events in municipal solid waste dumpsites

\begin{tabular}{|c|c|c|c|}
\hline Location & Year & Fatalities & Reference \\
\hline Payatas, Manila, Philippines & 2000 & 278 & Bernardo (2004); Merry et al. (2005); Palaypayon and Ohta (2006); Gaillard and Cadag (2009) \\
\hline Leuwigajah, Bandung, Indonesia & 2005 & 147 & This work; Koelsch et al. (2005) \\
\hline Belo Horizonte, Brazil & 1992 & $>100$ & http://www.humanite.presse.fr/journal/1992-03-20/1992-03-20-650098 \\
\hline Istanbul, Turkey & 1993 & 39 & Kocasoy and Curi (1995); Koerner and Soong (2000); Huvaj-Sarihan and Stark (2008) \\
\hline $\begin{array}{l}\text { Bantargebang, Bekasi, } \\
\text { West Java, Indonesia }\end{array}$ & 2006 & 28 & Suara Merdeka, 9 September 2006; personal field data \\
\hline Bogor, West Java, Indonesia & 2010 & 4 & http://www.jakartaupdates.com/74-municipal-waste-landfill-colapsed-killing-4 \\
\hline Cianjur, West Java, Indonesia & 2013 & 1 & http://nasional.news.viva.co.id/news/read/383558-bukit-sampah-longsor-lima-orang-tertimbun \\
\hline Tuban, East Java, Indonesia & 2012 & 1 & $\begin{array}{l}\text { http://news.detik.com/read/2012/06/22/190405/1948742/475/pencarian-korban-longsor-sampah- } \\
\text { pt-sg-di-tuban-dihentikan }\end{array}$ \\
\hline $\begin{array}{l}\text { Bantargebang, Bekasi, } \\
\text { West Java, Indonesia }\end{array}$ & 2012 & 1 & $\begin{array}{l}\text { http://www.beritasatu.com/megapolitan/48700-sampah-bantargebang-longsor-seorangpemulung- } \\
\text { tewas-tertimbun.html }\end{array}$ \\
\hline Athens, Greece & 2003 & - & Cited by Koelsch et al. (2005) \\
\hline Bulbul, Durban, South Africa & 1997 & & Blight $(2004,2008)$ \\
\hline Iriya, Tel-Aviv, Israel & 1997 & - & Isenberg (2003); Isenberg et al. (2004); Huvaj-Sarihan and Stark (2008) \\
\hline Doña Juana, Bogota, Colombia & 1997 & - & $\begin{array}{l}\text { GeoSyntec Consultants (1998); Hendron et al. (1999); Caicedo et al. (2002) ; Gonzales Garcia and } \\
\text { Espinosa Silva (2001) }\end{array}$ \\
\hline Bens, Coruña, Spain & 1996 & - & Landva and Dickinson (2000) \\
\hline Rumpke, Cincinnati, Ohio, USA & 1996 & - & Eid et al. (2000); Chugh et al. (2007); Evans \& Stark (1997); Schmucker and Hendron (1998) \\
\hline Leuwigajah, Bandung, Indonesia & 1992 & - & Personal field data \\
\hline Kettleman, California, USA & 1988 & - & Mitchell et al. (1990); Seed et al. (1990); Byrne et al. (1992); Chang (2005) \\
\hline Sarajevo, Bosnia & 1977 & - & Gandolla et al. (1979) \\
\hline Bandeirantes, Saõ Paulo, Brazil & 1991 & - & Bauer et al. (2008) \\
\hline
\end{tabular}

tensile stress $\zeta$, the normal stress $\sigma$, a transmission factor and a function considering the anisotropy (direction between the fibres and the shear plane). This method was used at Leuwigajah for a stability calculation conducted by Koelsch et al. (2005). A situation has been modeled without landfill fire. The overall stability amounted to $\eta=1.13$. A second modeling showed that the reinforcement particles in the upper part of the landfill were destroyed due to a smouldering landfill fire which burned over one month combusting waste particles like plastic fibres and foils. It was assumed that all tensile strength has been lost. Overall stability reduced from 1.13 to 1.00 . Therefore the dumpsite became unstable. Provided a proper construction and an appropriate operation, the landfill would not have faced any stability problems. According to Koelsch and Ziehmann (2004), landfill operators should follow two basic rules: to protect holding forces, and to reduce driving forces. Suggested operating measures are: (1) good compaction to reduce water percolation; (2) homogeneous permeability and efficient drainage system to prevent improper water balance; (3) forecast of the changes in waste composition and condition; and (4) measures to improve waste strength properties (e.g. use of combined liner system of mineral-synthetics). Unfortunately, solid waste landfills are still poorly managed in developing country, e.g. little landfill gas management, or often inadequate leachate management measures (Johannessen and Boyer G 1999).

\section{A difficulty to assess motion processes of waste avalanches}

The study focused on the motion processes of the waste, which are poorly known. It can be argued that the upper part of the waste mass moved downward through a sliding process, whereas the distal part displayed a flow motion, similar as a debris avalanche. Surprisingly, this statement is not consistent with the interpretations of formers studies (Table 1). Half of the events described in the literature were clearly defined as slides (e.g. at Kettleman in California, Istanbul, Coroña, Jakarta). Other events were described as waste flows similar to debris flows (e.g. at Bogota, Durban, Manila and maybe Belo Horizonte). However, the interpretations of the former studies were only based on visual observations by eyewitnesses, whereas the methods we used combined both eyewitness accounts and a field analysis of the internal structure of the waste deposits. This original approach for this kind of study allows us to state that both sliding and flow processes were involved during the 2005 waste 
avalanche at Leuwigajah. The type of movement, however, may be of different type depending on the internal structure of the material deposited in the dump and the origin of motion. Like natural slides, avalanches and debris flows the intrinsic scale and prior characteristics of the material involved may very well be the conditioning factor leading to a certain mechanisms of movement.

The volume of the 2005 collapsed waste $\left(2.7 \times 10^{6} \mathrm{~m}^{3}\right)$ is higher than any of the previous similar events (Table 1): their volumes did not exceed a few hundreds of thousands cubic meters at Bogota (1997) or Manila (2000), and reached $1.3 \times 10^{6} \mathrm{~m}^{3}$ at Istanbul (Kocasoy and Curi 1995), half the volume of the waste deposits at Leuwigajah. The large volume of water saturated waste at Leuwigajah, in addition to the explosion may explain the excessive runout up to $1000 \mathrm{~m}$. The high content of plastic bags (apparently more than $10 \%$, which is the highest proportion found in most of the municipal dumpsites - see Table 1 in Blight and Mbande 1998) could have also contributed to this excessive runup by reducing internal friction.

As mentioned above (see 4.2.1.), all the bodies of the victims were burnt. This fact, inconsistent with the heavy rains (see below 4.2.2), must be explained. It is probable that the high content of plastic bags, that constituted numerous quite impervious surfaces, formed a high number of parallel slippery surfaces parallel to the valley slope as attested by outcrops along the scar. This could have reduced the friction during the transport by both trapping rising methane emissions, and trapping the water percolating during heavy rains. Considering these assumptions together with all the characteristics of the movement and the data collected on site, the authors propose two potential scenarios (Table 2).

\section{Uncommon hazard, but predictable disaster}

Compared to the previous similar events documented in the scientific literature, the 2005 event displays some distinguishing features concerning both the hazard and the factors of vulnerability on site, which finally led to a major disaster.

The Leuwigajah disaster was predictable as it repeated similar events that have happened in other parts of the world. The waste slide indeed affected marginalized and vulnerable people who struggled to make a living out of the dumpsite. Poor people scavenging, sorting and selling rubbish to more powerful and affluent middlemen is a common pattern in Bogota, Belo Horizonte, Manila and Jakarta, and all these areas were affected by waste slide disasters in the recent decades. Children are the most vulnerable people facing waste slide hazard. On 16 March 2010, a 6-meter-high and 20-meter-long massive barrier fell down, killing four scavengers and badly hurting eight more people at the Galuga Municipal Waste storage in Cibungbulang, a suburb of Bogor city in Indonesia. Eleven of twelve victims were only 13 to 20 years old (Indonesia Today, posted online on 16 March 2010).

The abundant and constant flow of waste constitutes a significant resource for the poorest suburban communities. In Leuwigajah the amount of solid waste dumped was $14.7 \times 10^{6} \mathrm{~m}^{3}$ in 1999 (P.T. Perusahaan Gas Negara and Perusahaan Daerah Kebersihan Kota Bandung 2000). For those who migrate to the vicinities of large

Table 2 Two scenarios for waste avalanche initiation

\begin{tabular}{|c|c|}
\hline Scenario 1: failure due to dump mass saturation by rainwater & Scenario 2: failure triggered by explosion \\
\hline $\begin{array}{l}\text { (1) The infiltration of rainfall decreased the shear strength of the } \\
\text { dump, leading to its slide; }\end{array}$ & $\begin{array}{l}\text { (1) Heavy rainfall on the dump site led to increased water percolation through } \\
\text { the waste material. }\end{array}$ \\
\hline $\begin{array}{l}\text { (2) Once in motion, the disturbance of the mass structure allowed } \\
\text { large volumes of methane to contact smouldering waste, leading } \\
\text { to the explosions. }\end{array}$ & $\begin{array}{l}\text { (2) The percolating water reached the top of the combustion zone deeply } \\
\text { inside the waste mass. }\end{array}$ \\
\hline \multirow{4}{*}{$\begin{array}{l}\text { (3) The material experienced a long runout, because of the } \\
\text { intrinsically low internal friction of the saturated waste material, } \\
\text { aided by steam production. The 'still-hot' material would have } \\
\text { then also burnt the victims of the slide. }\end{array}$} & $\begin{array}{l}\text { (3) The vaporization of the water produced an increase of gas pressure at } \\
\text { the base of the dump that probably lifted up a part of it, resulting in } \\
\text { a sound-like explosion during the liberation of the accumulated } \\
\text { pressured gas. }\end{array}$ \\
\hline & $\begin{array}{l}\text { (1) The vaporization and the lift up processes combined their effects to } \\
\text { bring air to the combustion zone. The second and probably the third } \\
\text { explosion then occurred. }\end{array}$ \\
\hline & $\begin{array}{l}\text { (2) As the destabilized mass began to slide, the fire propagated to the whole } \\
\text { moving mass, helped by the significant amount of } \mathrm{CH}_{4} \text { trapped into the } \\
\text { waste material (numerous swirling flames were reported by eyewitnesses } \\
\text { and were probably due to the gas trapped in the plastic bags). }\end{array}$ \\
\hline & $\begin{array}{l}\text { (3) The combustion of each plastic bag within the moving mass produced } \\
\text { gas that allow an expansion of the whole mass to occur. Once started, } \\
\text { this mechanism, as well as water vaporization, triggered a self maintaining } \\
\text { expansion during the transport. This self maintaining expansion, responsible } \\
\text { of a friction reduction within the waste material, determined the unusually } \\
\text { high mobility of the moving mass and can also explain why the whole } \\
\text { material was deeply burned. }\end{array}$ \\
\hline
\end{tabular}


cities, dumpsites are an easily accessible resource to draw a living from as scavenging rubbish does not require specific skills. In the two villages next to Leuwigajah, it was estimated from interviews with key respondents that about $50 \%$ of the people were largely dependent on scavenging rubbish for their subsistence.

To these people the dumpsite is both a hazard and a resource but people brave the potential threat of waste slides on a seasonal basis to secure their daily needs. This was very evident in 1992 when a smaller waste slide occurred in Leuwigajah. Although seven houses were buried - fortunately no one died - people continued to scavenge rubbish as they did before. Similarly, in Payatas, Philippines, a waste slide buried several houses in 1999, or a year before the 2000 tragedy, but none of the affected families accepted the relocation scheme offered by the local government (Gaillard and Cadag 2009).

The immediate environment of dumpsites is usually considered as unsuitable for settlement by those who can choose where they live. On the other hand, for the most marginalized and poorest people, the cheap and often illegal nature of settlements near dumpsite is another resource as these people cannot afford more expensive rents in safe places (Blight and Mbande 1998). Settling far away from their primary mean of livelihood, i.e. the dumpsite, would also imply time and financial costs they cannot support. Interviews conducted after the Leuwigajah disaster showed that hundreds of families used to live within $500 \mathrm{~m}$ from the foot slopes of the Leuwigajah dumpsite. Most of these people further lived in houses made of scrap materials scavenged from the dumpsite. Such housing proved to be very vulnerable to urban fire and waste slide.

Since to the 2005 disaster, the Leuwigajah dump site has been abandonned, and progressively recovered by the natural vegetation (Figure 8), thanks to the high content of organic material in the waste deposits that allowed the formation of a soil. Since the 2005 disaster, the Bandung municipality lacks a suitable site and finances to construct a new sanitary landfill. Therefore West Java Province has planned to construct two new sanitary landfills outside Bandung Municipality at Legok Nangka (30 ha) and Leuwigajah (40 ha) to be used by Bandung Municipality. The contract has been signed in

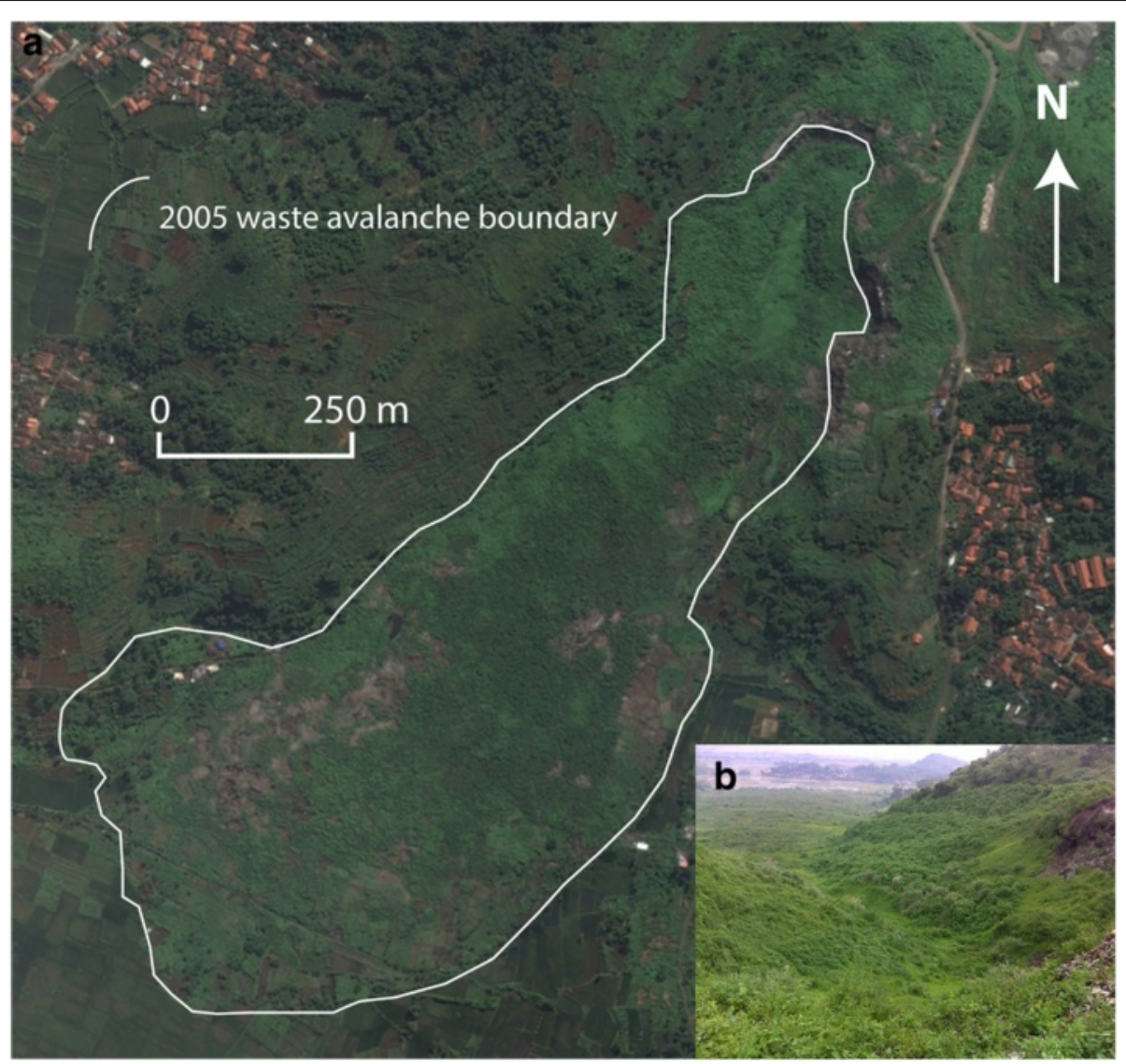

Figure 8 Post-disaster regreening of the Leuwigajah dump site in 2010. a. Aerial view of the waste avalanche deposits on 13 June 2010 (source: GoogleEarth). b. Oblic photograph taken from the scarp to the Southwest on 20 March 2010 (Courtesy: admbang setdaprovjabar on http://www.panoramio.com/photo/33538781). 
2012, and both sites were planned to be operational in 2014. Another project that encompasses the construction of an incinerator is highly criticized for ecological reasons (see http://www.sorgemagz.com/?p=3870 in Indonesian).

However, most of the other open dump sites in Indonesia are still uncontrolled, and therefore constitute a significant hazard for many communities. For example, the TPA Putri Cempo was built in 1985 in the vicinity of Surakarta (Central Java) for a scheduled life time of 15 years. However, this open dump site is still used today, although it remains unstable due to its overload and to the steep slope of its $9.5 \mathrm{~m}$ high front. Due to a rapid urban growth, all the large cities of Indonesia are concerned by the waste slide hazard, as exemplified by recent disasters or accidents (Table 1), e.g. at Bekasi in the vicinity of Jakarta in 2006 (28 deaths) and again in 2012, Bogor in 2010 (4 deaths), and Cianjur in 2013 (1 death). The transformation from uncontrolled open dump to controlled sanitary landfills is therefore highly recommended.

\section{Conclusion}

On the 21 February 2005 at 2.00 am, 143 people and 71 houses were buried under several meters of waste in motion initiated from the Leuwigajah dump site (Bandung, Indonesia). This disaster ranges second among the deadliest events of this type worldwide., The failure in the dump resulted from two triggering processes, i.e. heavy rainfall and consecutive explosions due to biogas sudden release. The flow initially moved as a slide, and then evolved into a flow. The waste avalanche extended as far as $1000 \mathrm{~m}$ from the scarp towards the paddy fields, due to the limited shear stress at the base of and within the waste in motion. Several factors may have played a key role in the shear stress reduction, e.g. the high quantity of biogas and water into the flowing mass, the very low weight of the material transported by the avalanche (plastic bags), the wet surface of the paddy field etc.

Whatever the natural triggers for the waste slide, the disaster cannot be dissociated from the extreme vulnerability of those marginalized people who died and suffered. Although previous waste slides occurred in the past the local government failed to both implement structural measures to stabilized the dumpsite and provide scavengers with alternative sustainable livelihoods. The amount of waste dumped in Leuwigajah actually sharply increased over the years before the disaster.

Only after the 2005 disaster did the activity of the dumpsite come to an end, and the local official in charge of the site was charged for not respecting the official recommendations regarding waste disposal and was sentenced to jail. In parallel, local communities complained about the closure of the dumpsite without appropriate alternative sustainable livelihoods. Although the disaster obviously brought some significant changes in Leuwigajah in the short term, the long-term prospects are bleak. A project by Environmental Protection Agency of West Java Province (BPLHD) has been planned for redeveloping a controlled landfill on the same site.

\section{Competing interests}

The authors declare that they have no competing interests.

\section{Authors' contributions}

FL, PW, CG, DSH, IP, TYWMI, MBH and MF conducted field work in Indonesia. JCG. and PT provided unpublished data on similar waste slide disasters in Indonesia and the Philippines. All the authors have contributed to data analysis, to discuss the results and to write the manuscript. JCG and TAD added useful comments to improve the paper. All authors read and approved the final manuscript.

\section{Acknowledgment}

Many thanks to the inhabitants of the villages that have been destroyed by the wasteslide for their cooperation. We are grateful to Center of Volcanology and Geological Hazard Mitigation Bandung who supported the spatial data of research area and some fieldworks conducted in 2005 and 2006. We also acknowledge Dr. Surono for his advises, and Bachtiar Wahyu Mutaqin for his technical help. We thank the anonymous reviewers who helped to improve the initial version of the paper.

\section{Author details}

'UMR 8591 Laboratoire de Géographie Physique, Paris 1 - Panthéon Sorbonne University, Meudon, France. '2UMR 8591 Laboratoire de Géographie Physique, University of Strasbourg, Meudon, France. ${ }^{3}$ College of Sciences, Department of Geography, University of Canterbury, Christchurch, New Zealand. ${ }^{4}$ College of Sciences, Department of Geological Sciences, University of Canterbury, Christchurch, New Zealand. ${ }^{5}$ Department of Geography, Center for Disaster Studies, Gadjah Mada University, Yogyakarta, Indonesia. ${ }^{6}$ School of Environment, The University of Auckland, Auckland, New Zealand. ${ }^{7}$ Denis Diderot - Paris 7 University, UMR 8586 Prodig, Paris, France. ${ }^{8}$ Jean Moulin University Lyon III, Lyon, France. ${ }^{9}$ Geological Museum, Geological Agency, Bandung, Indonesia.

Received: 18 August 2014 Accepted: 20 November 2014

Published online: 24 December 2014

\section{References}

Bauer J, Kölsch F, Borgatto AVA (2008) Stability Analysis According to Different Shear Strength Concepts Exemplified by two Case Studies. In: Ueda F (ed) Proceedings of the 5th APLAS. Sapporo (Japan)

Bernardo JY (2004) Payatas: Sense of Place in Contested Place. University of the Philippines Diliman, Quezon City

Blight GE (2004) A Flow Failure in a Municipal Solid Waste Landfill - the Failure at Bulbul, South Africa. Skempton Memorial Conference, London

Blight GE (2008) Slope failures in municipal solid waste dumps and landfills: a review. Waste Manage Res 26(5):448-463

Blight GE, Fourie AB (2005) Catastrophe revisited - disastrous flow failures of mine and municipal solid waste. Geotech Geol Eng 23:219-248

Blight GE, Mbande C (1998) Waste Management Problems in Developing Countries. In: Thomas-Hope E (ed) Solid Waste Management. Critical Issues for Developing Countries. Canoe Press University of the West Indies, Kingston, Jamaica, pp 11-26

Bray JD, Zekkos D, Kavazanjian EJ, Athanasopoulos GA, Reimer M (2009) Shear strength of municipal solid waste. ASCE J Geotechnical Geoenvironmental Eng 135(6):709-722

Byrne RJ, Kendall J, Brown S (1992) Cause and Mechanism of Failure Kettleman Hills Landfill B-19, Phase 1A. In: Stability and Performance of Slopes and Embankments II. Berkeley, 29 June-1 July 1992. ASCE Special Geotechnical Publication 31, New York, pp 1188-1215

Caicedo B, Giraldo E, Yamin L (2002) The Landslide of Dona Juana Landfill in Bogota. A Case Study. In: de Mello LG, Almeida MAA (eds) Environmental Geotechnics (4th ICEG). Balkema, Lisse, Netherlands, pp 171-175 
Chang M (2005) Three-dimensional stability analysis of the Kettleman Hills landfill slope failure based on observed sliding-block mechanism. Comput Geotech 32:587-599

Chugh AK, Stark TD, De Jong KA (2007) Reanalysis of a municipal landfill slope failure near Cincinnati, Ohio, USA. Can Geotech J 44(1):33-53

Eid HT, Stark TD, Evans WD, Sherry PE (2000) Municipal solid waste slope failure: waste and foundation soil properties. J Geotech Geoenviron Eng ASCE 126(5):397-407

Esmaili H (1975) Control of gas flow from sanitary landfills. J Environ Eng Div 101(4):555-566

Evans WD, Stark TD (1997) The Rumpke Landslide: New Information. Waste Age Magazine, Waste Systems and Technology, September 1997., pp 91-105

Gaillard J-C, Cadag JR (2009) From marginality to further marginalization: experiences from the victims of the July 2000 payatas trashslide in the Philippines. Jàmbá J Disaster Risk Stud 2(3):195-213

Gandolla M, Gabner E, Leoni R (1979) Stabilitätsprobleme bei nicht verdichteten Deponien: am Beispiel Sarajevo (Stability Problems with Compacted Landfills: the Example of Sarajevo). ISWA J

GeoSyntec-Consultants (1998) Investigation of the Causes of 27 September 1997 Zone II Slope Failure, Dona Juana Sanitary Landfill, Santafe de Bogota, Columbia, South America. Technical Report prepared for ProSantana Ltda. GeoSyntec Consultants, Chicago

Gonzalez Garcia A, Espinosa Silva A (2001) La Acumulación de Basuras como Material Geotécnico-II-Comportamiento de las Basuras. Revista de Ingeniería Universidad de Los Andes 14:56-70

Hendron DM, Fernandez G, Prommer PJ, Giroud JP, Orozco LF (1999) Investigation of the Cause of the 27 September 1997 Slope Failure at the Dona Juana Landfill. 7th International Waste Management and Landfill Symposium, Cagliari, Sardinia, Italy, pp 545-567

Huvaj-Sarihan N, Stark TD (2008) Back-Analyses of Landfill Slope Failures. 6th Intl. Conference on Case Histories in Geotechnical Engineering and Symposium in Honor of Prof. James K. Mitchell, Arlington, Virginia, pp 2-34

Isenberg RH (2003) Landfill and Waste Geotechnical Stability. USEPA Bioreactor Workshop, Crystal City, Virginia, USA, pp 1-29

Isenberg RH, Peterson ER, Sternberg D (2004) From landfill to leisure: closure and rehabilitation of hiriya landfill. Waste Manage World 2004:45-53

Johannessen LM, Boyer G (1999) Observations of Solid Waste Landfills in Developing Countries: Africa, Asia, and Latin America. Urban Development Division, Waste Management Anchor Team, The World Bank, ULG.WPS No3. World Bank, Washington DC

Kjeldsen P, Fisher EV (1995) Landfill gas migration: field investigations at Skellingsted landfill, Denmark. Waste Manage Res 13(5):467-484

Kocasoy G, Curi K (1995) The Ümraniye-Hekimbasi open dump accident. Waste Manage Res 13(4):305-314

Koelsch F (1996) Der Einfluss der Faserbestandteile auf dieScherfestigkeit von Siedlungsabfall. Mitteilungen des Leichtweiss-Institutes für Wassrbau der TU Braunschweig, Heft 133/96, ISSN 0343-1223 (PhD thesis)

Koelsch F, Fricke K, Mahler C, Damanhuri E (2005) Stability of landfills - The Bandung dumpsite disaster. Proceedings of the 10th International Landfil Symposium, Cagliari (Italy)

Koerner RM, Soong T-Y (2000) Stability Assessment Of Ten Large Landfill Failures. In: Zornberg JG, Christopher BR (eds) Advances in Transportation and Geoenvironnement Systems Using Geosynthetics. ASCE GSP №103, Denver, Colorado, pp 1-38

Kölsch F, Ziehmann G (2004) Landfill stability - risks and challenges. Waste Management World, issue Mai/June, ISWA, Copenhagen, Denmark, pp 55-60

Landva AO, Dickinson SJE (2000) Landslides in landfills. ISSMGE Bulletin 6, 1:10-18

Merry SM, Kavazanjian E, Fritz WU (2005) Reconnaissance of the July 10, 2000, Payatas Landfill Failure. J Perform Constructing Facil 19(2):100-107

Mitchell JK, Seed RB, Seed HB (1990) Kettleman hills waste landfill slope failure. I: Liner-system properties. J Geotech Eng 116(4):647-668

P.T. Perusahaan Gas Negara and Perusahaan Daerah Kebersihan Kota Bandung (2000) Studi kelayakan tentang pengembangan dan pengegolaan biogas dan produk sampingannya di tempat pembuangan akhir sampah (TPA) Pasir Impun, Jelekong dan Leuwigajah, Kota Bandung - Laporan Akhir (A feasibility study on development and management of biogas and its by-products in Pasir Impun, Jelekong and Leuwigajah landfills (TPA), Bandung city - Final Report). Bandung, Indonesia, Unpublished Report

Palaypayon M, Ohta H (2007) Estimation of shear strength parameters of municipal solid waste in landfills, Report submitted in participation to the JSPS. Core University Program Group 3
Pasang H, Moore GA, Sitorus G (2007) Neighbourhood-based waste management: a solution for solid waste problems in Jakarta, Indonesia. Waste Manage Res 27:1924-1938

Schmucker BO, Hendron DM (1998) Forensic Analysis of the 9 March 1996 Landslide at the Rumpke Sanitary Landfill, Hamilton County, Ohio. 12th GRI Conference Lessons Learned from Geosynthetic Case Histories, Geosynthetic Institute, Folsom, Pennsylvania, USA, pp 269-295

Seed RB, Mitchell JK, Seed HB (1990) Kettleman hills waste landfill slope failure. II: Stability analyses. J Geotech Eng 116(4):669-690

Stark TD, Eid HT, Evans WD, Sherry PE (2000) Municipal solid waste slope failure. II: stability analyses. J Geotech Geoenviron 126(5):408-419

Sub-Direktorat Mitigasi Bencana Geologi (2005) Penelitian Gerakan Tanah Di Desa Cibedug, Kecamatan Rongga, Kab. Bandung, Jawa Barat (Study of the Cibedug landslide, Rongga sub-district, Bandung district, West Java). Directorate of Volcanology and Geological Hazards Mitigation, Bandung, Indonesia

Sundana EJ (2005) Development of Regional Solid Waste Management Strategy in Indonesia: The Case Study of Greater Bandung Area. International Conference on Integrated Solid Waste Management in South East Asian Cities, Siem Reap, Cambodia, pp 5-7

Texier P (2009) Vulnérabilité et réduction des risques liés à l'eau dans les quartiers informels de Jakarta, Indonésie. PhD, Denis Diderot Paris 7 University, Paris

Woodward C (1997) Landfill Guidelines. Hazards of Burning at Landfills. Pollution and Waste Group, Ministry for the Environment, Wellington, New Zealand

Yachiyo Engineering Co (2009) Study for Integrated Environmental Improvement of Leuwigajah Disposal Site in West Java, Republic of Indonesia. Engineering and Consulting Firms Association, Tokyo, Japan

doi:10.1186/s40677-014-0010-5

Cite this article as: Lavigne et al:: The 21 February 2005, catastrophic waste avalanche at Leuwigajah dumpsite, Bandung, Indonesia. Geoenvironmental Disasters 2014 1:10.

\section{Submit your manuscript to a SpringerOpen ${ }^{\circ}$ journal and benefit from:}

- Convenient online submission

- Rigorous peer review

- Immediate publication on acceptance

- Open access: articles freely available online

High visibility within the field

- Retaining the copyright to your article

Submit your next manuscript at $\gg$ springeropen.com 